\title{
Energy and Environmental Impact on the Biosphere Energy Flow, Storage and Conversion in Human Civilization
}

\author{
Thomais Vlachogianni, Athanasios Valavanidis* \\ Department of Chemistry, University of Athens, University Campus Zografou, Athens, Greece \\ *Corresponding author: valavanidis@chem.uoa.gr \\ Received December 14, 2012; Revised April 09, 2013; Accepted April 25, 2013
}

\begin{abstract}
The present review describes the role of different energy regimes throughout the human history and their environmental impact. The appearance of Homo sapiens and the development of primitive human civilization can be narrated by different energy regimes throughout the centuries. Getting the energy that humans needed for their needs affected directly the environment in many different ways. Some energy sources have a greater impact than others. Energy is lost to the environment during any energy transformation, usually as heat. Environmental historian can describe human history, from the discovery of fire (the most important human invention) by the primitive man and the development in four different energy regimes over the last ten thousand years. The first two divisions, "gatherer-hunters" (1.5 million to 10,000) and "pre-industrial agriculture," cover many centuries until 1750. The third period deals with "an industrial world" up to 1950, and the fourth period covers the developments in the post industrial society, between 1950 and the $21^{\text {st }}$ century. Energy usage divides periods of socio-ecological human history. In each period, human energy sources and consumption changed significantly, providing a point of no return. Until the 1700s, however, agriculture continued to rely on energy directly related to the sun and stored in organic systems. After 1750, humans developed new ways of thinking about nature, as well as new kinds of energy systems based on coal and the production of steam. New energy systems (petroleum, natural gas, hydroelectric) allowed a dramatic increase in human populations but at the same time polluted quite heavily damaging the environmental balance with nature. Those increases changed dramatically after 1950 and caused the doubling of the population and the multiple energy use for transport and electricity. Are nuclear energy and renewable energy sources the future prospects for a sustainable development in energy use by humans? Is the "Third Industrial Revolution" the future solution for global warming? These are hard questions with great implications on the future of the planet, its ecological balance and inevitably for the human civilization.
\end{abstract}

Keywords: energy flow, use of energy, human history, human civilization, industrial society, human population

\section{Introduction}

Many environmental historians who studied the links between natural environment of planet Earth and human civilization, provided a new historical narrative of human society development as an integrated approach to the forms of energy use, flow, storage and conversion. The historical context of human development was seeing through the ages of the available energy on the planet and its use for fundamental changes in survival and material production. The mastery of controlled fire was a cornerstone in the relationship of humans with the Earth's biosphere. This mastery distinguished humans from other mammals. The ability of humans to manipulate fire permitted early humans to tap the solar energy that was stored in plants and wood (biomass) and to transform extensively the natural environment and the exploitation and use natural resources [1,2].

Environmental historians have devised a different chronology of human history according to the energy regimes. They subdivided the energy regimes into two ages [1].

1. The age of solar energy (from the origins to c. 1800 A.D) with four distinct periods

a. Hunter-gatherers discovering and mastering fire in a controlled environment for heat and food cooking (2-1.5 million BC- 10.000 BC),

b. Early farming communities-agricultural civilizations $(\sim 10.000$ BC),

c. Early agrarian age under regional empires $(5,000 \mathrm{BC}$ $1400 \mathrm{AD})$,

d. Late agrarian age (1400-1800 AD). Intensification of farming

2. The age of fossil fuels. Industrial Revolution (1800 AD- to the present time).

a. early fossil-fuel era (coal and steam),

b. late fossil-fuel era (petroleum oil, natural gas).

3. The age of renewable energy sources and nuclear power (photovoltaics, hydrogen, wind power, geothermal heat, etc), post industrial period from 1945 to present. Human society is from the energy point of view at the 
cross-roads. The threat of global warming, the need for the development of sustainable energy sources and environmental protection are key components for future survival.

Scientists who explored the entire history of the universe found that energy was the predominant mover of the genesis and evolution of the cosmos. The Big Bang 13.7 billion years ago was the ultimate fire story which provided the initial expanding energy for the entire universe, forming galaxies, stars, planets and dark matter. The Earth is one of the billions of planets that was endowed with organic life. Central to life on Earth is the photosynthesis through which the solar energy was captured and stored by plants and later used by other biological systems to develop into complex life forms $[1,2,3,4]$.

\section{The Discovery and Mastery of Controlled Fire by Humans}

All archaeological evidences until now suggest that the discovery of fire was the key factor that brought big changes in human development. The human history can be described as a series of major impacts on the surrounding natural environment mediated through the discovery of fire and various sources for energy use. The controlled use of fire was an invention of the Early Stone Age (or Lower Paleolithic). The earliest evidence for controlled use of fire is placed at the Lower Paleolithic site of Gesher Benot Ya'aqov in Israel, where charred wood and seeds were recovered from a site dated 790,000 years ago [5].

The timing of the human control of fire is a hotly debated issue, with claims for regular fire use by early hominins in Africa at $\sim 1.6$ million years ago. These claims are not uncontested, but most archaeologists would agree that the colonization of areas outside Africa, especially of regions such as Europe where temperatures at time dropped below freezing, was indeed tied to the use of fire. Scientists noted that beginning about 400,000300,000 years ago, there is strong evidence for the use and reuse of fire including the hafting of stone tools is found in several Middle Paleolithic caves and open air sites.[6] Human ability to manipulate fire and the landscape has increased over evolutionary time, but the impact of this on fire regimes and consequences for biodiversity and biogeochemistry are hotly debated.

\section{Fire, Diet, Human Evolution and Brain Size in Mammals}

Fire improved efficiency in manipulating the surrounding environment (safety from predators, clearing land, visibility during night time). Homo sapiens was the only mammal that changed its natural environment according to its needs of the time. Fire helped tremendously in the production and storage of food thus affecting the population density. Fire must have improved sanitation and helped in the extermination of microorganisms and insects. Humans learned to light fires in the dry season and to transform the landscape through grazing and cultivation. Substantial human impacts on burned area in Africa were directly responsible for the development and the evolution of human primitive societies [7].

Fire influenced substantially the behavior of humans. Primitive thinking about nature changed, human felt that transformation of the environment was achievable. Activity was no longer restricted to the daylight hours. In addition, some dangerous mammals (predators) and biting insects avoid fire and smoke. Fire also led to improved nutrition by cooked proteins. Richard Wrangham (British primatologist, Professor of Biological Anthropology at Harvard University, Department of Human Evolutionary Biology) argues that cooking of plant foods may have triggered brain expansion by allowing complex carbohydrates in starchy foods to become more digestible and in effect allow humans to absorb more calories [8].

Wrangham has also suggested that eating cooked food is more "natural" for the human digestive system, because the human digestive system may have evolved to deal with cooked foods, and that cooking explains the increase in hominid brain sizes, smaller digestive tract, smaller teeth and jaws and decrease in sexual dimorphism that occurred roughly 1.8 million years ago. He argued that raw meat and vegetables could not have provided the necessary calories to support the hunter-gatherer lifestyle [9].

Most anthropologists disagree with Wrangham's ideas, pointing out that there is no solid evidence to support Wrangham's claims. The mainstream explanation is that human ancestors, prior to the advent of cooking, turned to eating meats, which then caused the evolutionary shift to smaller guts and larger brains. Anthropologists opposing Wrangham stating that archeological evidence suggests that cooking fires began in earnest only 250,000 BP (before present), when ancient hearths, earth ovens, burnt animal bones, and flint appear across Europe and the Middle East [10].

Two million years ago, the only sign of fire is burnt earth with human remains, which most other anthropologists consider to be mere coincidence rather than evidence of intentional fire. The mainstream view among anthropologists is that the increases in human brain-size occurred well before the advent of cooking, due to a shift away from the consumption of nuts and berries to the consumption of raw animal foods (meat) [11,12].

A recent paper (2012) by scientists of the Institute of Biomedical Sciences (Rio de Janeiro, Brazil) supports with new evidence the idea that shift to cooked food by Homo erectus helped in the development of large number of brain neurons and thus had a major positive contribution to rapid increase in brain size in human evolution [13].

\section{Human History and Energy Regimes}

Environmental geographers tend to describe the relations of human development and environment in four different energy regimes over the last ten thousand years. The first division is considered the period of, "gathererhunters" and the second is the phase of "pre-industrial agriculture". These two phases cover the period from the origins of the first groups of hunters for the collection of food up to the 1750 ("industrial revolution"). The third 
period deals with "an industrious world" up to 1950, and the fourth period is the phase of human history with modern developments between 1945 (nuclear energy, renewable sources) and 2010. Geographers in their description of these periods use a wide variety of materials, including scientific, historical, and archaeological studies and data on the nature of the environment, ecosystems and the changes in the biosphere in the last 10.000 years of the Earth's history [14].

Energy usage divides each period, human energy sources and consumption changed significantly, providing a point of no return. Hunter-gatherers needed a big area to search for sustenance produced yearly by energy delivered by the sun. They made a significant environmental impact by setting fires that helped to burn away what they did not want and allow what they did want to grow more plentifully. Bending plants and animals to their own needs produced agriculture and its own set of cultural and environmental impacts. Until the 1700s, however, agriculture continued to rely on energy directly related to the sun and stored in organic systems (crops, trees) [14].

After 1750, humans developed new ways of thinking about nature, as well as new kinds of energy systems based on coal and the production of steam. The exploitation of natural resources became fundamental part of developing technologies. Today, about $80 \%$ of the world's energy consumption is sustained by the extraction of fossil fuels. Intensive agriculture is another example of nature's exploitation and energy storage. New energy systems allowed a dramatic increase in human populations. Inevitably detrimental human impact on the environment increased substantially. Those increases changed dramatically after 1945 that and new energy relationships with the natural environment developed. Human population quadrupled in the last 100 years into 7 billions [14].

\section{Energy Produced in the Solar System by the Sun}

The solar system is a group of planetary bodies in the spiral galaxy of the Milky Way. The sun is a hot ball of glowing gases at the heart of our solar system. Its influence extends far beyond the orbits of distant Neptune and Pluto. Without the sun's intense energy and heat, there would be no life on Earth. We must realise that there are billions of stars like the Sun scattered across the Milky Way galaxy [15].

The Sun (born roughly 4.6 billion years ago from a giant, rotating cloud of gas and dust) holds $99.8 \%$ of the solar system's mass and is roughly 109 times the diameter of the Earth. The visible part of the sun is roughly 10,000 degrees $\mathrm{F}\left(5,500\right.$ degrees $\left.{ }^{\circ} \mathrm{C}\right)$. The temperatures in the core of the Sun reach more than 27 million degrees F (15 million degrees $\left.{ }^{\circ} \mathrm{C}\right)$. The high temperature is the result of thermo-nuclear reactions. One would need to explode 100 billion tons of dynamite every second to match the energy produced by the Sun $[16,17]$.

The energy of this sunlight supports almost all life on Earth by photosynthesis and drives Earth's climate and weather. The Sun has enough nuclear fuel to stay much as it is now for another 5 billion years. Eventually, it will shed its outer layers, and the remaining core will collapse to become a white dwarf and then will enter its final phase as a dim, cool object sometimes known as a black dwarf. Just like most other stars, the sun is made up mostly of hydrogen (H) (75\%), followed by Helium (He) $(23.8 \%)$ and $1 \%$ of seven other elements: oxygen, carbon, neon, nitrogen, magnesium, iron and silicon. The Sun inherited its chemical composition from the interstellar medium out of which it was formed. Hydrogen and helium were produced by the Big Bang nucleosynthesis [18].

\section{How Much Energy is Produced by the Sun? How Much is Received by the Earth}

The Sun generates nearly 386 billion million gigawatts ( 1 gigawatt $=10^{9}$ watts) every second $\left(3.8 \times 10^{26}\right.$ watts $\left./ \mathrm{sec}\right)$, most of which is electromagnetic radiation. This energy represents explosions of 4 billion hydrogen bombs of 100 megatons each. This process of generation of sun's energy is termed as nuclear fusion. Fusion of the Hydrogen atoms forming Helium (He) and energy. There are various energy equations for the overall nuclear fusion in the Sun. In order to realize how much energy is produced by comparison, a nuclear reactor makes only one gigawatt of energy per second. Only a fraction of the Sun's radiant energy reaches the Earth [19].

The Earth receives 174 petawatts $\left(\mathrm{PW}, 1\right.$ petawatt $=10^{15}$ watts)) of solar radiation from the Sun at the upper atmosphere. Only 1\% of Sun's energy reaching Earth is used effectively (photosynthesis and warming up oceans, atmosphere and land surfaces). Organic life (through photosynthesis) uses only $0.023 \%$ of the energy that reaches the surface of the Earth. Another higher percentage warms land and oceans. Whereas 35\% of Sun's energy is wasted because it is reflected back to space.

The average total global energy consumption for one year (2010) on Earth was about 16 tetrawatts ( 1 petawatt $=$ 1.000 terawatts, petawatt $=10^{15}$ watts $)$. Energy absorbed by the oceans and land masses keeps the surface at an average temperature of $14^{\circ} \mathrm{C}$ (ideal for biological organisms).

Most of the solar energy on Earth is stored in green plants and our food supply is completely dependent on solar energy. After plants die, they decay in the Earth, so solar energy can be said to provide the biomass that has created the fossil fuels that we are dependent on. It is very interesting to note that only one-billionth $(1 / 1.000 .000 .000)$ of the total energy that the Sun produces reaches Earth [20].

\section{Paleolithic Era: Tools and Fire of Hunter-Gatherers}

For at least 3 million years, during the evolution of Homo sapiens from a primitive mammal, mankind used tools and fire unlike the other animals to carry the basic activities of hunting (of fishing). These changes helped to their survival. Humans are very unusual among animals in combining the two functions that helped in their evolution. Language and ability to communicate effectively were 
very important and have been greatly helped in establishing a primitive use of nature and its resources. Wild animals' meat, fish, plants, tubers, trees were used for feeding an increasing population. Some of their materials were used for protection, tools, arrows and sticks.

The story of controlled fire started from the Paleolithic era (250,000-100,000 B.C.E.) that lasted until the beginning of farming. The agricultural civilization, 10,000 B.C.E. (abbreviation Before Common/ Current/ Christian Era) was the most important development. The early hunter-gatherers first incorporated the use of fire into processing food. The controlled fire played a pivotal part in their hunting life style, reduced many dangers with predators and through the use of tools contributed effectively to keep them healthy and productive, aspects that contributed to the population increase $[21,22]$.

At around 20,000 B.C.E. the success of their life-style with the help of fire resulted in the distribution of huntergatherers all around the world. At this time population on Earth was estimated to around 8-10 million. But the increase of population of hunter-gatherers could not be sustained forever and they had to find new forms of energy, increasing food production, gathering and storage. Predators, diseases, high newborn mortality, short life expectancy, and low fertility kept the population in balance with natural resources than from increasing rapidly [23].

\section{Agriculture and Human Population on Earth}

The population on Earth increased only after the establishment of agriculture in the Fertile Crescent region $(\sim 10,000 \mathrm{BCE}$, present Syria and Iraq). Before the invention of agriculture, population never exceeded 15 million all over the Earth. Estimates varied for the total human population between 8-15 million. With the beginning of farming, the safety of adequate food and the organized societal life inevitably increased life expectancy and fertility. In 1340 the population reached 450 million, but the Great Famine and Black Death in the next decades decreased the population to 370 by 1350 Similarly, in China the population from 123 million in 1200 decreased to 65 million in 1393, because of plagues and the Mongol invasion. Despite the plagues and high mortality from infectious/parasitic diseases the population of humankind reached one billion in 1804 [24].

So why the human societies of hunter-gatherers changed into farmers? This is a profound question that many archaeologists had to answer. Mark Cohen in the 1970s first suggested that agriculture was born out of desperation, rather than inspiration [25,26]. Evidence from the Fertile Crescent seems to support him. Rising human population density, combined perhaps with a cooling, drying climate, left the Natufian hunter-gatherers of the region short of acorns, gazelles and wild grass seeds (Natufian culture is the name given to the sedentary hunter-gatherers living in the Levant region Eastern Mediterranean region, present Israel, between about 12,500 and 10,200 years ago). They were hunter-gatherers, foraging for wheat, barley and almonds, and hunting gazelle, deer, cattle, horse, and wild boar.
The largest Natufian communities (called 'base camps') found to date include Jericho, Ain Mallaha, and other areas. Archaeologists presume that somebody started trying to preserve and enhance a field of chickpeas or wheat-grass and soon planting, weeding, reaping and threshing were born. At about 12,000 years ago people embarked on an experiment called agriculture. Farming brought a population explosion, protein and vitamin deficiency, new diseases and deforestation. The big changes started, approximately, 10,000 years ago when people first discover how to cultivate crops and to domesticate wild animals. This is the most significant single development in human history. Plentiful of water and flooding rivers (Tigris river, Euphrates rivers, Nile Delta) played an important part. Wild plants with edible parts were very easy to collect and give adequate food and energy. Domestication of animals provided the important ingredient of animal protein and fat that complement human diet. The annuals (plants, crops) of the Fertile Crescent were highly abundant and suitable for cultivation, meaning the area boasts some of the earliest examples of domesticated plants, dated at 8,500 BC [27].

According to Jared Diamond in his book Guns, Germs and Steel there were five locations where plant domestication originated independently: the Fertile Crescent in Southwest Asia, China, Mesoamerica, the Andes and Amazonia, and the Eastern United States. The reason agriculture originated in each case was due to the particular plant species present $[28,29,30]$.

\section{The First Farmers from 8,000 B.C.: Storing Energy by Photosynthesis and the Surplus Production of Food}

The fundamental biochemical process on Earth for energy storage from the sun was Photosynthesis. This is a process used by plants, algae and bacteria to convert the light energy captured from the sun into chemical energy with the involvement of carbon dioxide and water, releasing oxygen as a waste product which is vital for all aerobic life on Earth.

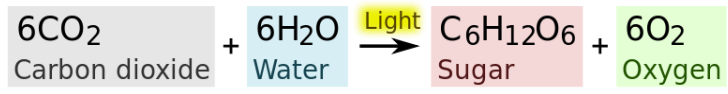

Photosynthesis is the source of energy for nearly all life on Earth. The average rate of energy capture by photosynthesis globally is immense, approximately 130 terawatts, which is about six times larger than the power consumption of human civilization. Photosynthetic organisms convert around 100-115 thousand million metric tons (i.e., 100-115 petagrams) of carbon into biomass per year (Straub F. Photosynthesis. World of Wonder. The Creative Company, Mankato, Minnesota, 2003).

Agriculture was the key development in the rise of human civilization, Humans developed the expertise for good farming practices through chance and error. Their advanced brains made the connections with access to water, seasons, sun light, quality of soil and how to wait for better yields $[31,32]$. 
Domestication of wild animals was the next process. The process of domestication inherently takes many generations over a long period of time. It is believed that the first attempt at domestication of both animals and plants were made by peoples of the Mesolithic Period. The tribes that took part in hunting and gathering wild edible plants, started to make attempts to domesticate dogs, goats, sheep and pigs which was as early as $9000 \mathrm{BC}$. The most important places that agricultural methods take place are in the Middle East, in America, in China and in Southeast Asia [33,34].

Domestication of wild animal species (surplus food for animal feeding) was a crucial achievement in the prehistoric transition of human civilization from huntingand-gathering to agriculture. The first domesticated livestock animal may have been the sheep, which was tamed around 9000 BC in Northern Iraq. Around 5500 BC there were domesticated cattle in South West Iran; and around $3500 \mathrm{BC}$ the horse was domesticated on the Eurasian steppes [35,36].

Archaeological findings showed that the place known to have lived mainly from the cultivation of crops is Jericho (Israel-Palestine). By around $8000 \mathrm{BC}$ this community, occupying a naturally well-watered region. Farmers were growing selected forms of wheat (emmer and einkorn are the two varieties), soon to be followed by barley. Though no longer gatherers, these people were still hunters. Their source of meat was wild gazelle, cattle, goat and boar. It is no accident that Jericho is also the first known town, with a population of 2000 or more. A pioneering agricultural community, surrounded by other tribes dependent on gathering food, offers easy pickings which will need vigorous protection. Jericho had protective walls and a tower [37].

\section{Early Agrarian Age (5000 BC-1400 AD). More Efficiency in Energy Transformation from the Sun}

The early agrarian age that lasted almost 7,000 years witnessed many changes in agricultural practices (new crops, irrigation, plowing etc) but in energy storage the regime remained the same. Population increases in all parts of the world were inevitable because of surplus food production and better hygiene (lower infant mortality, less infectious diseases).

The Mesopotamian agriculture was a prototype for the early agrarian age. Barley was the primary crop; wheat, flax, dates, apples, plums, and grapes were also grown as well. But farming was limited by flooding from the Tigris and Euphrates rivers. Sheep and goats were domesticated, kept mainly for meat and milk, butter and cheese. Ur (present North Iraq), a large town had 10,000 animals kept in sheepfolds and stables and 3,000 slaughtered every year. The city's population of 6,000 included a labor force of 2,500 and cultivated 3,000 acres of land. The horse was domesticated in Ukraine around $4000 \mathrm{BC}$, and was in use by the Sumerians around 2000 BC $[38,39,40]$.

In classical antiquity, Roman agriculture built from techniques pioneered by the Sumerians, transmitted to them by subsequent cultures. The agriculture had specific emphasis on the cultivation of crops for trade and export.
Romans laid the groundwork for the manorial economic system, involving serfdom, which flourished in the Middle Ages. In China there were similar farming systems but many innovations. Books in the $6^{\text {th }}$ century described land preparation, seeding, orchard management, forestry and animal husbandry. The Chinese had innovated hydraulicpowered trip hammer, the waterwheel, oxen pulling, pumps and pipes for water irrigation (lifting water to higher elevations). In India farming was advanced as far as 9,000 BCE. Wheat, barley, and jujube were cultivated. Domestication of sheep and goat soon followed. By the 5th millennium BCE agricultural communities became widespread in Kashmir. Cotton was cultivated by the 5 th millennium BCE. Irrigation was developed in the Indus Valley Civilization by around 4500 BCE. Archeological evidence of an animal-drawn plough dates back to 2500 BC in the Indus Valley Civilization [41]. In the Andes region of South America the major domesticated crop was potatoes, domesticated perhaps 3000 B.C.E. Large varieties of beans were domesticated, in South America, as well as animals, including llamas, alpacas, and guinea pigs. The Incas civilization produced a variety of adaptation of agricultural technologies that already were used previously. These technological advances allowed the Incas to organize the production of a diversity of products in coast, mountain and jungle areas and redistributed to villages that did not have access to other regions $[41,42,43]$.

\section{Late Agrarian Age (1400-1800 AD). Better Farming Techniques More Energy, Better Nutrition}

The transformation of agricultural societies after the $1400 \mathrm{AD}$ was rapid because of the application of substantial improvements in agricultural practices. In the British isles better nutrition and shelter, lower infant mortality and prevention of infectious diseases increased the population from around 5 million to 16 million by $1800 \mathrm{AD}$, despite the migration of substantial numbers to North America and the Caribbean. This was a pattern that was repeated in France and in Central Europe (Germany).

The agricultural production increased substantially through different improvements in crop farming and animal husbandry. Storing food is like storing energy for later use. In fact, in the late agrarian practices humans achieved more storage of energy into food and better yields for the same effort. Introduction of new crops and practices was part of the late agrarian revolution [43].

At the same time agricultural mechanization applied in farming practices increased crop production. A typical example is the British innovator Jethro Tull, (1674-1741) who introduced the seed drill, a device for sowing seeds effectively. Also, he advocated the use of horses instead of oxen and invented a horse-drawn hoe for clearing weeds. The use of horses to plow instead of the slower oxen made plowing more efficient and improved soil fertility. New breeding techniques of live stock gave the opportunity for better and more efficient food production. By 1770 English farmers were producing $300 \%$ more food than in 1700 , with only a small increase (14\%) in the number of farm workers [44]. 


\section{Deforestation and non Sustainable Expanding Human Population}

All these advances in agricultural techniques formed the basis for substantial increase of the Earth's population but inevitably after some centuries reached their limit. Growth in terms of food, shelter and material wealth met with sustainability problems because of the limitations of used natural resources. The most formidable environmental problem in Europe was deforestation. Wood was used for many purposes. It provided energy for cooking and heating interiors, whereas charcoal was used for the production of iron (and other metals). Wood and trees were also used for the construction of wooden houses, furniture, barrels, windmills, and ships. A warship in the late $17^{\text {th }}$ century needed 3,500 trees. The results were very obvious and forests were devastated in many parts of the world [45].

From 1100 to $1500 \mathrm{AD}$, significant deforestation took place in Western Europe as a result of the expanding human population. After 1250 they became so skilled at deforestation that by 1500 they were running short of wood for heating and cooking. They were faced with a nutritional decline because of the elimination of the generous supply of wild game that had inhabited the nowdisappearing forests, which throughout medieval times had provided the staple of their carnivorous high-protein diet. By 1500 Europe was on the edge of a fuel and nutritional disaster from which it was saved in the sixteenth century only by the burning of soft coal and the cultivation of potatoes and maize The system of agricultural production and the use of forests for energy was not sustainable and other means had to be found to help the development of the human civilization. By the $17^{\text {th }}$ century large areas in Britain, Denmark, central Europe and Low Countries lost their forests and large mammals had disappeared because of deforestation [46].

Deforestation is not only the loss of trees. Erosion of soil (exposing the soil to the sun and rain, making it very dry and eventually infertile because of loss of nutrients), disruption of the water cycle (the groundwater tables are affected, water is just runs off, loss of water resources), loss of biodiversity (especially tropical forests), flooding and droughts (forests absorb and store water, protects soil) and finally Climatic change were caused largely from reduced absorption of carbon dioxide by plants. The replacement of wood with other materials for energy was imperative for the survival of the human civilization on planet Earth. Global deforestation sharply accelerated around 1852. It has been estimated that about half of the Earth's mature tropical forests-between 7.5 million and 8 million $\mathrm{km}^{2}$ (2.9 million to 3 million sq mi) of the original 15 million to 16 million $\mathrm{km}^{2}$ (5.8 million to 6.2 million sq mi) that until 1947 covered the planet have now been destroyed. Some scientists have predicted that unless significant measures are taken on a worldwide basis, by 2030 there will only be only $10 \%$ of remaining forests, with another $10 \%$ in a degraded condition. It is estimated that $80 \%$ of forests will have been lost, and with them hundreds of thousands of irreplaceable species [47].

\section{Revolutionary Energy Use. Early Fossil- fuel Era and Industrial Revolution}

The period from 1750 to 1914 was a pivotal moment in human history. Historians have named it the era of the "modern revolution" (or industrial revolution). The most important event was the revolutionary transformation in the use of energy by humans. Until the 19th, the energy basis of human society had been biomass energy, mainly the burning of wood to produce heat. But when fossil fuel (coal) was introduced as an energy source a "revolution" occurred in a few decades with unprecedented global changes. Until the 1750s, the economy all over the world was almost exclusively an organic economy, harvesting energy and materials from the earth's surface ecosystems. Food, fuel, shelter, motive power, clothing, and virtually every other necessities of life were obtained from plants, animals, falling rivers, and blowing winds. The growth potential of organic economies remained sharply constrained by the limited ability, when of the energy regime reached its limits [48].

Fossil minerals (coal in the beginning, oil and natural gas-methane later) in the late 1700 s were initiated in England for the first time. Coal-powered technologies magnified the energy needed and the industrial revolution was born. Coal's impact was particularly dramatic in the industrial sector, but fossil fuels were also changing people's domestic lives in important ways. By 1914, petroleum, a second major fossil fuel, began to be extensively used as well with more energy efficiency and then natural gas was the third important fossil fuel that produced equally substantial energy stocks for consumption [48].

The Industrial Revolution began in the textile industry in England, where a series of inventions created new demands for labourers. Between 1733 and 1793, inventors produced new machines that led to the growth of the factory system, which brought workers and machines together in one place to manufacture goods. By the late 1700 s, steam (produced from coal) began to replace water as a source of power (Thomas Newcomen and James Watt). Steam engines gave a boost to coal and iron and transport industries that were essential to the Industrial Revolution [48].

During the Industrial Revolution, advances were made in transportation and communication. In Britain a mining engineer, George Stephenson, developed the first steampowered locomotive, opening the way for the building of railroads. Railroads and steam-powered ships improved transportation around the world. Colonies supplied raw materials and bought finished goods $[49,50]$.

\section{The Late Fossil-fuel Era (Petroleum Oil, Natural Gas)}

The use of coal was pivotal but slowly was replaced by oil (petroleum) and natural gas $\left(\mathrm{CH}_{4}\right.$, methane) which are more efficient in energy production and transport and less damaging to the environment. The cross-over happened in the mid 1960s and marked the beginning of the Age of Oil. Also, natural gas after the 1960s increased substantially and consumption as a fuel and exceeds now coal. Also, natural gas and petroleum are used as feedstock materials for the chemical industry.

Energy consumption after 1918 increased by a large percentage (electricity and vehicle use). A second spurt in 
energy use started about the time of World War II. Developed and underdeveloped countries all over the world increased their energy consumption because of substantial needs for electricity and motorcar fuels. Between 1950 and 2000 there is a substantial increase of energy consumption, despite the increase in oil prices. China, India and other developed countries became industrial powers $[51,52]$.

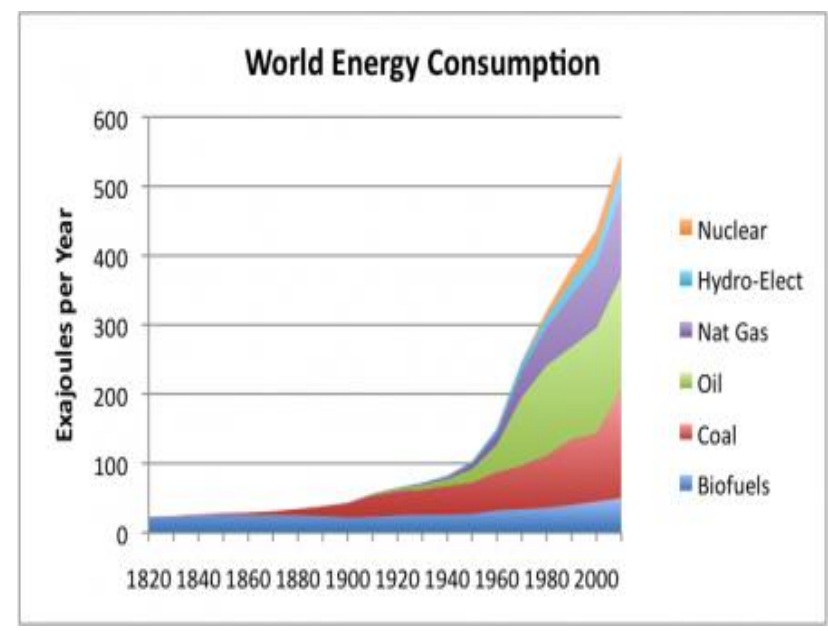

Figure 1. World Energy Consumption (1820-2000) by Source, Based on Vaclav Smil book [Smil V. "Energy Transitions: History, Requirements and Prospects". Santa Barbara, CA, 2010] estimates, together with BP

Statistical Data for 1965 and subsequent years

Modern human societies are based on very high paced consumption of fossil energy which has been constantly growing over the last century. It is a fact that $85 \%$ of global energy use at present is relying on fossil fuels and the substitution with renewable energy sources is very slow and financially difficult to achieve. Most scientists remain skeptical to the fact that humans can preserve their modern lifestyle following the same high rate of energy consumption as USA and Europe. In the last decades China, India and almost all developing countries follow similar western style consumption of fossil fuels. This explains the desperate search for alternative and sustainable energy sources and changes in energy consumption.

The post-industrial economic growth in the majority of countries is associated with the absolute dependence on fossil fuels. The ongoing depletion of fossil energy stocks (despite the discovery of new oil fields) indicated that human societies had to decrease fossil energy consumption and to redirect their efforts for renewable energy sources $[53,54]$.

The problem of fossil energy use and the future of the planet are interconnected (global warming, rising levels of oceans, biodiversity, population growth, infectious diseases, etc). The enormity of the challenge for the humanity means that all countries should do their part to encourage the societal and technological shift towards sustainable and improved energy systems. Humans can no longer afford to ignore the clarion call of the future. Instead humans must plan ahead and strive toward energy sustainability and security. The drive to create a new energy system can only be beneficial to the future of the human race and planet Earth. This new and cleaner energy system (renewable) will assist in reducing the rapid rise in greenhouse gas emissions that is now accepted as the most important contributor to global warming $[55,56]$.

\section{Energy from Nuclear Power (Uranium -235). Is Nuclear Power a Renewable Energy Source?}

Nuclear power stations use of sustained nuclear fission (of Uranium -235) to generate heat and electricity. Worldwide, nuclear power plants provide about $6 \%$ of the world's energy and $13-14 \%$ of the world's electricity. The U.S., France, and Japan together accounting for about $50 \%$ of nuclear power generated electricity. In 2007, the International Atomic Energy Agency (IAEA, Vienna) reported that there were 439 nuclear power reactors in operation in the world, in 31 countries. Also, more than 150 naval vessels using nuclear propulsion have been built [57].

For years there was an ongoing debate about the use of nuclear energy. Proponents were argued that nuclear power can be considered as a sustainable energy source that reduce carbon dioxide emissions and climatic changes. While opponents believe that nuclear power poses many threats to people and the environment, as well as problems of weapons proliferation and international safety. The nuclear power stations became very important after the 1973 oil crisis and the significant increase of the price of petroleum which threatened the energy production in many industrialized countries. Some local opposition to nuclear power emerged in the 1960s. Also, members of the scientific community began to express their concerns. These concerns related to nuclear accidents, nuclear proliferation, high cost of nuclear power plants, nuclear terrorism and radioactive waste disposal. In the early 1970s, there were large protests about a proposed nuclear power plant in Wyhl, Germany (was cancelled in 1975). The success of the anti-nuclear protests inspired opposition to nuclear power in other parts of Europe and North America [57].

Since their development, the economics of new nuclear power plants is a controversial subject among scientists and environmentalists. Nuclear power plants typically have high capital costs for building the plant, but low fuel costs. Therefore, comparison with other power generation methods is strongly dependent on economic assumptions as well as for energy storage solutions for intermittent power sources $[58,59]$.

The debate changed dramatically the last decades with the global warming issue caused by $\mathrm{CO}_{2}$ by the conventional electricity generation and vehicular use of oil. The argument is that nuclear power can be considered as non-polluting energy production. Scientists argue that with the use of nuclear power humans can mitigate global warming and reduce substantially the emissions of $\mathrm{CO} 2$ until; other renewable and non-pollution energy sources are invented. Life cycle analysis (LCA) of CO2 emissions show nuclear power as comparable to renewable energy sources. Emissions from burning fossil fuels are many times higher [60,61].

According to the United Nations Scientific Committee on the Effects of Atomic Radiation, UNSCEAR, regular nuclear power plant operation including the nuclear fuel 
cycle causes radioisotope releases into the environment amounting to $0.0002 \mathrm{mSv}$ (milli-Sievert) per year of public exposure as a global average. This level is very small compared to variation in natural background radiation. As of a 2008 report, the remaining legacy of the worst nuclear power plant accident (Chernobyl) is $0.002 \mathrm{mSv} / \mathrm{yr}$ in global average exposure $[62,63]$.

The dramatic climatic change on Earth brought the solution of nuclear energy to the forefront in the last decade. However, the 2011 nuclear accident at Japan's Fukushima I Nuclear Power Plant and other problems with safety in various nuclear facilities raised questions among commentators over the future of nuclear power. Although some countries commissioned new nuclear power stations (Finland, China, India) Germany decide to close its nuclear power stations after 2020. The crisis at Japan's Fukushima nuclear plants has prompted leading energy-consuming countries to re-evaluate their nuclear energy programs for the future. Although nuclear power is considered a low carbon power generation source, its legal inclusion with renewable energy power sources has been the subject of great debate. Nuclear fission is not regarded as renewable by the U.S. Department of Energy [63,64].

James Lovelock has argued in his book "The Revenge of Gaia" that the climate crisis can be reversed by using the nuclear power for electricity because is the only energy source that does not produce ant $\mathrm{CO}_{2}$. Some scientists have very strong arguments against nuclear energy and support the opinion that the use of nuclear power station will not solve the problem of energy demand. The cost of nuclear fuel, nuclear waste, terrorism, nuclear proliferation and decommissioning are negative aspects $[64,65,66]$.

A thorough study of the antinuclear movements in Germany and the USA described the main arguments of popular organizations in these two highly industrialised countries against nuclear power. France in the other hand derives over $75 \%$ of its electricity from 58 nuclear power stations. This is due to a long-standing policy of the French government and with the understanding of a large percentage of the population based on energy security [67].

\section{Transitioning from a Carbon-Intensive Economy to a Low-Carbon Future. Can We Avoid Climatic Change?}

Over the past century, human activities have released large amounts of $\mathrm{CO}_{2}$ and other greenhouse gases $\left(\mathrm{CH}_{4}\right.$, $\mathrm{O}_{3}, \mathrm{CFCs}, \mathrm{NO}_{\mathrm{X}}$ ) into the atmosphere. The majority of greenhouse gases come from burning fossil fuels to produce energy, although deforestation, industrial processes, and some agricultural practices also emit gases into the atmosphere. Greenhouse gases act like a blanket around the Earth's atmosphere, trapping energy (in the form of radiation) and causing it to warm.

Scientists are measuring the levels of $\mathrm{CO}_{2}$ and the mean temperature for decades. Earth's average temperature has risen by $0.8^{\circ} \mathrm{C}\left(1.4^{\circ} \mathrm{F}\right)$ over the past century (two-third after the 1980s). Scientists are projecting that by 2100 the rise of global temperature (estimations with low and high limits according to the measures taken in the future) from 1.1 to $6.4^{\circ} \mathrm{C}\left(2\right.$ to $\left.11.5^{\circ} \mathrm{F}\right)$. Small changes in the average temperature of the planet can translate to large and potentially dangerous shifts in climate and weather. The scientific evidence is clear. The planet's oceans and glaciers have also experienced some big changes - oceans are warming and becoming more acidic, ice caps are melting, and sea levels are rising [68].

The increasing use of fossil fuel in the last decades for energy (electricity, fuel for industry) and transport contributed to the substantial emissions of $\mathrm{CO}_{2}$ that is the main contributor to greenhouse effect. The United Nations Intergovernmental Panel on Climate Change (IPCC) published a special report on "Renewable Energy Sources and Climate Change Mitigation" in 2011. The report evaluated the global potential for using renewable energy to mitigate climate change.

The Special Report of IPCC "aims to provide a better understanding and broader information on the mitigation potential of renewable energy sources: technological feasibility, economic potential and market status, economic and environmental costs \& benefits, impacts on energy security, co-benefits in achieving sustainable development, opportunities and synergies, options and constraints for integration into the energy supply systems and in the societies" The report notes that: government policies play a crucial role in accelerating the deployment of renewable technologies. Under most conditions, increasing the share of renewable energy in the energy mix will require policies to stimulate changes in the energy system [69].

The Worldwatch Institute in New York is a very famous environmental organization with many publications and reports. The Institute with the "Worldwatch's Energy and Climate Change Program" aims to accelerate the transition to a low-carbon economy based on sustainable use of renewable energy sources in concert with major energy-efficiency gains, sustainable agricultural practices, and low-emissions transportation. This transition will be expensive and difficult, Worldwatch research shows that it would create vast economic opportunities, spur innovation and job creation, and assist efforts to reduce poverty while providing a more resilient and sustainable global economic system. Worldwatch works to inform decision makers about the potential for a low-carbon future and to develop and communicate policies and strategies that can best achieve that goal $[70,71]$.

The transition from a carbon-intensive economy to a low-carbon future presents numerous technological challenges but also great opportunities for developing countries to move into sustainable energy sources. It is almost a scientific fact for many experts that the future of the planet cannot be sustainable with the present energy regime. Scientists suggest that only sustainable energy roadmaps and renewable energy sources can help countries successfully navigate the change to an infrastructure capable of meeting the energy challenges of the 21 st century. The cost will be substantial, the consumption of fossil-fuel energy must be cut to a minimum and sustainable sources must be found. Renewable resources potential for renewable energy production such as wind, solar, small hydropower and biomass must be promoted and subsidised against fossilfuel energy production. There is a need for existing energy infrastructure to increase efficiency and energy storage. 
The current socio-economic and policy environments must identify barriers to low-carbon development and rely on international best practices [70,71].

\section{Is There Hope for Sustainable Development? Can Renewable Energy Sources Substitute Fossil Fuels?}

In the last decades there is a rapid advance in the use of renewable energy sources and sustainable use of energy. Renewable energy sources are important for the future of the Earth and the survival of human societies. Renewable energy sources are considered: solar energy, wind power, biomass, hydrogen, geothermal, ocean and hydropower energy. There are many advantages from changing into the use of renewable sources, but there are also some disadvantages and difficulties compared with the fossil fuels and other non-renewable energy sources. The sun, wind, geothermal, ocean energy are available in the abundant quantity, without limits and free to use. Renewable sources have low carbon emission and are environment friendly, can stimulate the economy and create jobs. Renewable sources, many researchers suggest, can provide cheaper energy for transport and electricity with modern technological advances.

The disadvantages of renewable energy sources are that are not easy to set up energy park and the initial cost is very high. Solar and wind energy have high cost for the technological construction. Solar panels and wind turbines are not producing energy at all times. Geothermal energy can release toxic gases and affect the environment. Hydroelectric power need expensive dams across rivers (with negative effects on wildlife). At present renewable energy sources produce around $15 \%$ of energy needs of human societies and it is expected for substantial rate of increases in the future [72,73].

Strong interest in renewable energy arose in the 1970s as a response to the shortage and high price of imported oil, which disrupted the orderly operation of the economies and societies of many developed countries. Today there are new motivations, including the realization that growing greenhouse gas emission accelerates global warming and threatens climate change, the growing dependence of many countries on foreign oil, and the economic drain of foreign oil payments that slow economic growth and job creation. There are three ultimate sources of all renewable and fossil energies: sunlight, the heat in the earth's core and crust, and the gravitational pull of the moon and sun on the oceans. Renewable energies are relatively recently developed and typically operate at lower efficiencies than mature fossil technologies. Like early fossil technologies, however, renewable energy sources can be expected to improve their efficiency and lower their cost over time, promoting their economic competitiveness and widespread deployment [73,74].

The future deployment of renewable energies depends on many factors, including the availability of suitable land, the technological cost of conversion to electricity or other uses, the costs of competing energy technologies, and the future needs for energy on the global scale Scenario analyses indicate that renewable energies are likely to be technically and economically capable of supplying most of the world's electricity needs in 2050. In addition to cost, public acceptance is a key factor in the widespread deployment of renewable energy $[74,75,76]$.

\section{Renewable Energy Sources. Are We Witnessing a "Third Industrial Revolution"?}

Human history gave us many examples of civilizations collapsing because they misused the environment. Natural environment and human civilization grew side by side for many centuries on the understanding that there is sustainable development and environmental protection at the same time. Energy regimes played fundamental role in development of human society and the dramatic increase in energy exploitation.

The dramatic rise of greenhouse gases emissions from the burning of fossil fuels is raising the earth's temperature and threatening an unprecedented change in the chemistry of the planet and global climate, with ominous consequences for the future of human civilization and the ecosystems of the Earth. While oil, coal and natural gas will continue to provide a substantial portion of the world's energy (for developing and developed countries) well into the 21 st century, there is a growing consensus that we are entering a twilight period where the full costs of our fossil fuel addiction is beginning to act as a drag on the world economy $[77,78]$.

According to the well known scientist Jeremy Rifkin in his lecture."The Third Industrial Revolution. Leading the way to green energy era and a hydrogen economy", writes: "....Looking to the future, every government will need to explore new energy paths and establish new economic models with the goal of achieving as close to zero carbon emissions as possible. The great pivotal economic changes in world history have occurred when new energy regimes converge with new communication regimes..."[79].

"...A great communications revolution occurred in the 1990s. Second generation electrical forms of communication - personal computers, the internet, the World Wide Web, and wireless communication technologies - connected the central nervous system of more than a billion people on Earth at the speed of light. And although the new software and communication revolutions have begun to increase productivity in every industry, their true potential is yet to be fully realized. The creation of a renewable energy regime, partially stored in the form of hydrogen, and distributed via smart intergrids, opens the door to a Third Industrial Revolution and should have a powerful and economic multiplier effect in the $21^{\text {st }}$ century.." [80].

The five pillars of the so-called "Third Industrial Revolution" infrastructure are listed below: [80]

A. Shifting as soon as possible to renewable forms of energy,

B. Buildings as Power Plants: New technological breakthroughs to design and construct buildings that create all of their own energy from locally available renewable energy sources, allowing us to reconceptualize the future of buildings as "power plants", 
C. Using Internet technology to transform the power grid of every continent into an energy sharing intergrid,

D. Deploying Hydrogen and other storage technologies in every building and throughout the infrastructure to store intermittent energies,

E. Transitioning the transport fleet to electric, plug in and fuel cell vehicles that can buy and sell electricity on a smart continental interactive power grid.

The theory (because in practice it needs great international efforts) for the "Third Industrial Revolution" argues that conjoining Internet communication technology and renewable energies will give in the future rise to an advanced Green economy and mitigate climate change [80].

\section{Conclusions}

Environmental historians provided a new historical narrative of human society development as an integrated approach to the forms of energy use, flow, storage and conversion. Human development was seeing through the ages of the available energy on the planet. Controlled fire for most scientists was the cornerstone in the relationship of humans with the Earth's biosphere and distinguished humans from other mammals. Controlled fire improved efficiency in manipulating the surrounding environment and helped in the production and storage of food thus affecting the population density. With the beginning of farming $10,000 \mathrm{BC}$, the safety of adequate food and the organized societal life inevitably increased the human population but also affected the natural environment. Agriculture was the key development in the rise of human civilization.

Until the 1750s, the economy all over the world was almost exclusively an organic economy. Fossil minerals changed all that and brought forward the industrial revolution, thus changing the rules of the game between humans and the natural environment. Modern human societies are based on very high paced consumption of fossil energy which has been constantly growing over the last century. The problem of fossil energy use and the future of the planet are interconnected (global warming, rising levels of oceans, biodiversity, population growth, etc). The enormity of the challenge for the humanity means that it is imperative to organize a technological shift towards sustainable, renewable energy sources and improved energy systems.

For some scientists, humanity needs a "Third Industrial Revolution" which it is hoped to bring a new era of energy use, improved productivity and at the same time mitigate global warming. Humans have the science and the technology to make it happen.

\section{References}

[1] Burke E III. The Big Story. Human History, Energy Regimes, and the Environment. In: Burke E, III, Pomeranz K (Eds). The Environment and World History. University of California Press, Berkeley, London, pp. 33-53, 2009.

[2] Pyne SJ. World Fire: The Culture of Fire on Earth. Holt publishing, New York, 1995.

[3] Smil V. General Energetics: Energy in the Biosphere and Civilization. John Wiley \& Sons, New York, 1991.

[4] Goudsblom J. Fire and Civilization. Penguin, London, 1992.
[5] Goren-Inbar N, Alperson N, Kislev ME, Simchoni O, Melamed Y, Ben-Nun A, and Werker E. Evidence of Hominin Control of Fire at Gesher Benot Ya'aqov, Israel. Science 304 (5671):725-727, 2004.

[6] Roebroeks W, Villa P. On the earliest evidence for habitual use of fire in Europe. Proc Natl Acad Sci USA 108 (13): 5209-5214, 2011.

[7] Archibald S, Staver AC, Levin SA. Evolution of human-driven fire regimes in Africa. Proc Natl Acad Sci USA 109(3):847-852, 2012.

[8] Wrangham RW, Jones JH, Laden G, Pilbeam D, Conclin-Ritain A. The raw and the stolen. Cooking and the ecology of human society. Curr Anthropol 40(5):567-570, 1999.

[9] Wrangham R. Catching Fire: How Cooking Made Us Human. Basic Books, New York, 2009.

[10] Milton K. The critical role played by animal source foods in human (Homo) evolution. J. Nutr. 133 (11, Suppl.2):3886S-3892S, 2007.

[11] Mann N. Meat in the human diet: An anthropological perspective. Nutrition \& Dietetics 64 (Supplement S4): 102-107, 2007.

[12] Gorman RM. Cooking up bigger brains. Scientific American 298:102-105, 2008.

[13] Fonseca-Azevedo K, Herculano-Houzel Z. Metabolic constraint imposes tradeoff between body size and number of brain neurons in human evolution. Proc. Natl Acad Sci , USA, 109 (45): 1857118576, 2012.

[14] Simmons IG. Global Environmental History $10.000 \mathrm{BC}$ to $\mathrm{AD}$ 2000. Edinburgh University Press, Edinburgh, 2008.

[15] Backman D, Seeds MA. The Solar System. Thomson/Brooks/Cole, Belmont, CA, 2007, \& 2010.

[16] Chaisson E, McMillan S. Astronomy Today: The Solar System, Benjamin Cummings, San Francisco, CA, New York, $6^{\text {th }}$ ed. 2007.

[17] Freedman RA, Kaufmann NJ. Universe: The Solar System. WH, Freeman \& Co, New York, $3^{\text {rd }}$ ed. 2008.

[18] Jastrow R, Rampino M. Origins of Life in the Universe. Cambridge University Press, Cambridge, New York, 2008.

[19] Golub L, Pasachoff JM. Nearest Star: The Surprise Science of Our Sun. Harvard University Press. Cambridge, MA, 2001.

[20] Hill S, Carlowitz M. The Sun. Harry N. Abrams, New York, 2006.

[21] Gibbons A. The First Human: The Race to Discover Our Earliest Ancestor. Anchor, Imprint of Random House, New York, 2007.

[22] Stringer C, Andrews P. The Complete World of Human Evolution. Thames \& Hudson, London, $2^{\text {nd }}$ ed. 2012.

[23] Cochran G, Harpending H. The 10,000 Year Explosion: How Civilization Accelerated Human Evolution. Basic Books, New York, 2010.

[24] Larsen C. "Changes in human populations with agriculture". Annual Review of Anthropology 24: 185-236, 1995.

[25] Cohen MN., Armelagos GJ. Paleopathology and the Origins of Agriculture. Academic Press, Orlando, Fla, 1984.

[26] Cohen MN. Health and the Rise of Civilization, Yale University Press, New Haven, 1977.

[27] Russell K. Eden: The Behavioral Ecology of Early Food Production in the Near East and North Africa. Oxford University Press, Oxford, 1988.

[28] Diammond JD. The Third Chimpanzee: The Evolution and Future of the Human Animal. Harper Perrenial, Harper Collins, New York, 2006.

[29] Diamond JD. Guns, Germs, and Steel: A Short History of Everybody for the last 13,000. Vintage, London, 1997 (2005).

[30] Diamond JD. Guns, Germs, and Steel: The Fates of Human Societies. WW Norton \& Co, New York, 1997.

[31] Price TD, Gebauer AB (Eds). Last Hunters, First Farmers: New Perspectives on the Prehistoric Transition to Agriculture. School of American Research Press, Santa Fe, New Mexico, 1995.

[32] Smith BD. Emergence of Agriculture. Scientific American Library, W.H. Freemen \& Co, New York, 1999.

[33] Brown TA, Jones MK, Powell W, Allaby RG. "The complex origins of domesticated crops in the Fertile Crescent". Trends Ecol Evolution 24(2):103-109, 2008.

[34] Barker G. The Agricultural Revolution in Prehistory: Why Did Foragers Become Farmers? Oxford University Press, Oxford, 2009.

[35] Lev-Yadun S, Gopher A. Abbo S. "The cradle of agriculture". Science 288:1602-1603, 2000.

[36] Cohen NM. "Introduction: rethinking the origins of agriculture". Curr Anthropol 50:591-595, 2009. 
[37] Kenyon KM. “Ancient Jericho”. Scientific American 190(4):76-82, 1954.

[38] Oppenheim AL, Reiner E. Ancient Mesopotamia: Portrait of a Dead Civilization. University of Chicago Press, London, 1964, 1977.

[39] Roux G. Ancient Iraq. Penguin Books, London, 1992 ( $3^{\text {rd }}$ ed) (first 1964).

[40] Van de Mieroop M. A History of the Ancient Near East ca. 3000323 BC. Blackwell, Oxford, 2004.

[41] Richerson PJ, Borgerhoff Mulder M, Vila BJ. Principles of Human Ecology, Pearson Custom Publishing, New York, 1996.

[42] Johnson AW, Earle T. The Evolution of Human Societies: From Foraging Group to Agrarian State. Stanford University Press, Stanford, CA, $2000\left(2^{\text {nd }} e d\right)$.

[43] Bellwood P. First Farmers: The Origins of Agricultural Societies. Wiley-Blackwell, New York, 2004

[44] Miller E. The Agrarian History of England and Wales. Cambridge University Press, Cambridge, 3 volumes (Volume III 13481500AD), 1991.

[45] Williams M. Deforesting the Earth: From Prehistory to Global Crisis. An Abridgment. University of Chicago Press, London, 2006.

[46] Chew SC. World Ecological Degradation: Accumulation, Urbanization, and Deforestation. 3000 BC-AD 2000. AltaMira Press, New York, 2001.

[47] Vajpeyi DK. Deforestation, Environment, and Sustainable Development: A Comparative Analysis. Praeger, Westport, CT, USA, 2001.

[48] Ashton TS, Hudson P. Industrial Revolution, 1760-1830. Oxford University Press, Oxford, New York, 1998.

[49] Allen RC. The British Industrial Revolution in Global Perspective. Cambridge University Press, Cambridge, UK, 2009.

[50] Mokyr J (Ed). The British Industrial Revolution. An Economic Perspective. Westview Press, Boulder, CO, New York, ( $2^{\text {nd }}$ ed.), 1998.

[51] Montgomery SL. The Powers That Be: Global Energy for the Twenty-first Century and Beyond. University of Chicago Press, Chicago, 2010

[52] Smil V. Energy Myths and Realities. Bringing Science to the Energy Policy Debate. American Enterprise Institute for Public Policy Research, Washington DC, 2010.

[53] Goodstein D. Out of Gas: The End of the Age of Oil. WW Norton \& Co, New York, London, 2004.

[54] MacKay DJC. Sustainable Energy-Without the Hot Air. UIT Cambridge Ltd, Cambridge, 2009.

[55] Boyle G. Renewable Energy: Power for a Sustainable Future. Oxford University Press, Oxford, ( $2^{\text {nd }}$ ed.), 2004.

[56] Evans RL. Fueling Our Future: An Introduction to Sustainable Energy. Cambridge University Press, Cambridge, UK, 2007.

[57] IAEA. International Nuclear Information System. Nuclear Energy.----reference, World numbers- the International Atomic Energy Agency (Vienna) [ http://www.iaea.org/inis/ ], assessed February 2013.

[58] Murray LR. Nuclear Energy: An Introduction to the Concepts, Systems and Applications of Nuclear Processes. ButterworthHeinemann, London, 2009.
[59] Cravens G, Phodes R. Power to Save the World: The Truth About Nuclear Energy. Vintage Books, New York, 2008.

[60] Ferguson CD. Nuclear Energy: What Everyone Needs to Know. Oxford University Press, Oxford, New York, 2011.

[61] Morris R. Environmental Case for Nuclear Power: Economic, Medical and Political Considerations. Paragon House, New York, 2000.

[62] Tucker N. Terrestrial Energy. How Nuclear Power Will Lead the Green Revolution and End America's Energy Odyssey. Bartleby Press, Savage, MD, 2008.

[63] Herbst AM, Hopley GW. Nuclear Energy Now: Why the Time Has Come for the World's Most Misunderstood Energy Source. John Wiley \& Sons, New York, 2007.

[64] Lovelock J. The Revenge of Gaia. Earth's Climate Crisis and the Fate of Humanity. Allen Lane, London, 2006 \& Basic Books, New York, 2006.

[65] Caldicott H. Nuclear Power Is Not the Answer. The New Press, New York, (distributed by WW Norton \& Vo, New York), 2006.

[66] Kaku M, Trainer J. Nuclear Power Both Sides: The Best Arguments For and Against the Most Controversial Technology. WW Norton \& Co, New York, 1983.

[67] Joppke C. Mobilizing Against Nuclear Energy. A Comparison of German and the United States. University of California Press, Berkeley, CA, 1993.

[68] Environmental Protection Agency (EPA, USA). Climate Change Basics. (http://www.epa.gov/climatechange/basics/).

[69] IPCC. Special Report on Renewable Energy Sources and Climate Change Mitigation. Intergovernmental Panel on Climate Change. Archived from the original on 2011-05-09. Retrieved from (http://en.wikipedia.org/w/index.php?title=Renewable_Energy_So urces_and_Climate_Change_Mitigation\&oldid=514576981).

[70] Worldwatch Institute. Report No. 187.Sustainable Energy Roadmaps: Guiding the Global Shift to Domestic Renewables. Worldwatch Institute, New York, 2012

[71] Worldwatch Institute. Low-Carbon Energy: A Roadmap. Worldwatch Institute, New York, 2008.

[72] Twidell J, Weir T. Renewable Energy Resources. Taylor \& Francis, London, New York, 1986 ( $2^{\text {nd }}$ ed.), 2006.

[73] Boyle G. Renewable Energy: Power for a Sustainable Future. Open University Press, Oxford, ( $3^{\text {rd }}$ edition), 2012.

[74] Witzel W, Seifried D. Renewable Energy. The Facts. Earthscan, London, 2010, Routledge, London, 2010.

[75] Freris L, Infield D. Renewable Energy in Power Systems. John Wiley \& Sons, Chichester, W. Sussex, UK, 2008.

[76] Sorensen B. Renewable Energy. Physics, Engineering, Environmental Impacts, Economics and Planning. Academic Press, London, New York, 2010.

[77] Ponting, C., A Green History of the World: The Environment and the Collapse of Great Civilizations. Sinclair-Stevenson, London, 1991.

[78] Redman, C. L. Human Impact on Ancient Environments. University of Arizona Press, Tempe, AZ, 1999.

[79] Rifkin J. The Third Industrial Revolution. Leading the way to a green energy era and a hydrogen economy (www.thethirdindustrialrevolution.com).

[80] Rifkin J. The third Industrial Revolution: How Lateral Power is Transforming Energy, the Economy, and the World. Palgrave Macmillan Publishers, New York, 2011. 